\title{
The Dynamics of Asy-syuro Mosque's Role in Cipari Village in 1912-2015 as Social Studies Learnings Source
}

\author{
(Descriptive Study on the change of Asy-syuro Mosque's Role in aspects of
} Ritual, Social, Economy, Education, Da'wah, Politics, and Health)

\author{
Nurul Fauziah ${ }^{1}$, Muhammad Iqbal ${ }^{2}$, Wildan Insani Fauzi ${ }^{3}$ \\ ${ }^{1}$ Madrasah Aliyah Ashshidiqiyyah, Garut, Indonesia \\ ${ }^{2,3}$ Social Science Education Study Program, Faculty of Social Science Education \\ Universitas Pendidikan Indonesia, Bandung, Indonesia
}

\begin{abstract}
This study was conducted since there is a problem of limited social studies learning source for junior high school or SMP. Mostly, teachers only provide textbooks or other learning material, but do not use environment as the source of social studies learning. Thus, learning source which uses environment is highly needed, such as role Dynamics of Asy-syuro Mosque in 1912-2015, which aims to increase students' enthusiasm in learning social studies in class and to make students understand the lesson more easily because they can see it directly. In this research, the case study method was used because the researcher carefully observed the role of Asy-syuro Mosque in the Pre Independence (1912-1945) and the Post-Independence (1949-2015) periods. Data collection technique of this study was through Literature study, Observation, interview, and documentation study. The subjects of this study are the family of the mosque's founder, Asy-syuro Mosque management, Cipari village's elders, social studies teachers, and students of MTs Ponpes Cipari. Based on the research, it is found that Asy-syuro Mosque had a quite significant role change in seven aspects (Ritual, Social, Economy, Education, Da'wah, Politics, and Health). The role of Asy-Syuro Mosque in politics in 1912, 1945 and 1949 has values and meanings of great fighting, togetherness, cooperation, and nationalism soul. This case is included into learning source "Message" component. Meanwhile, AsySyuro Mosque's role in other aspects, has piety, responsibility, concern, honesty, values and as the application of Social Interaction and Social Motives Economic Action materials. These are included into learning source "Environment" type. Asy-Syuro Mosque is a kind of "Learning Resources by Utilization" which uses environment or surroundings and is relevant to social studies learning material.
\end{abstract}

Keywords: Dynamics, Asy-syuro Mosque's Role, Social Studies Learning Source

Correspondence.uyuykiainf@gmail.com

Article History. Received January 2019, Received in revised March 2019, Accepted June 2019

C2019. International Journal Pedagogy of Social Studies. Department of Social Studies Education

\section{INTRODUCTION}

Learning is an act of human nature as an effort to carry out life's quality. Through learning process, every individual can find many potentials he/she has, particularly potentials whicg include cognitive domain, skills, and behaviours. Learning-teaching process is an interaction among learners with various learning sources in a learning environment. Learning-teaching activity is an educational process.
Essentially, education is a process to develop human who can recognize him/herself and explore the potentials they have, also who can understand real life facts around them, locally, nationally and globally. National education development is always oriented toward development of human resources (SDM) which aims to reach national superiority.

The purpose of national education can be achieved through various activities; one of 
them is social studies (IPS) learning activity, which aims to understand and develop knowledges, values, attitudes, social skills, and to be able to reflect in society, nation, and country. One of the significant breakthroughs in education world is the birth of new curriculum which pays great attention for local cultured wisdom-based education developmemt (Susanto, 2014, p. v-vi). This breakthrough purposes to waken awareness and attention of people of education in exploring and developing education which based on local culture sourced from local potentials.

Social studies and local wisdom are a blend which should not be separated because the essence of social studies learning is to integrate local wisdom values and nation's noble values into social studies learning process. Local wisdom-based social studies learning is expected to raise locak potentials which are still marginalized from public attention and to build students' character through the values contained in it. Therefore, students will not feel bored and will understand the subject more easily.

The researcher was interested in a mosque close to her house, which is Asy-Syuro Mosque in Cipari, Sukarasa Village, Pangatikan sud-district, as the focus study's object. The reasons for choosing it are uts art deco-styled architecture and its old building which is known as mute witness of fighting against Dutch and DI/TII, and also it has values. After the researcher made a preresearch activity on January 25, 2019, some problems in the field were found, which are social studies learning tends to be boring and students were not got used to understand materials and to relate them to everyday life.

As described above, the researcher was interested to conduct a study entitled "The Dynamics of Asy-syuro Mosque's Role in Cipari Village in 1912-2015 as Social Studies Learnings Source", because the researcher can see the changes of role function of Asy-Syuro Mosque in Cipari Village in Pre-Independence (1912-1945) and Post-Independence (19492015) periods, and can re-improve the existence of Asy-Syuro Mosque to Indonesian people. The researcher also cab obtain educational values from those roles which are relevant to social studies learning materials to make the learning not boring because students also can be closer and considerate to surroundings.
Social studies or IPS term in Indonesia has been known since 1970s as a result of academic community's agreement and formally applied in national education system and Kurikulum 1975. James A. Banks (1990, p. 3) in his book "Teaching Strategies for Social Studies" defines social studies or IPS as a part of primary and secondary school curriculums which have primary responsibility to help students developing their knowledge, skills, and attitudes, as stated by NCSS (in Sapriya, 2009, p. 39) that:

"Social studies is the integrated study of social sciences and humanities to promote civic competence. Within the school program, social studies provides coordinated, systematic study drawing upon such disiplines as anthropology, archaeology, economics, geography, history, law, philosophy, political science, phycology, religion, and sociology, as well as appropriate content from the humanities, mathematics, and natural sciences. The primary purpose of social studies is to help young people develop the ability to make informed and reasoned decisions for the public good as citizens of a culturally diverse, democratic society ini an interdependent world".

Social studies have four (4) dimensions, namely: knowledge, skills, values and attitude, and action. From the four dimensions, students who learn social studies are expected to be able to apply their knowledge into skills, attitude, and action. It relates to the Purpose of Social studies learning in Kurikulum 2013, which is proposed by Sapriya (in Hasanah and Darmawan, 2016, p. 2) regarding the social studies subject's purpose:

"Regarding concepts related to society and environment, having basic skills to think logically and critically, curiousity, inquiry, problem solving and skills in social life, having commitment and awareness, and having communication and cooperating skills, and competing in plural society, in local, national, and global levels.

The purposes of social studies subject achieved is supported by social studies learning process is designed by teachers, by using learning material development approach which is always linked to society.

In social studies learning, its principle and urgency is that theory or knowledge is created by the students themselves and can be applied in everyday life, so the learning has meaningful result (Wijaya, 2016, p. 5). It is 
where learning context refers to contextual teaching and learning. As proposed by Mina Holilah (2015, p. 165), that contextual approach becomes new alternative to correlate social studies material with contemporary social issues around students's environment. Thus, it attracts students' attention to learn social science.

Teacher can utilize natural potentials around students which are really near and easy to obtain as learning sources to help delivering material in learning. Valentine $(2015$, p. 224) argues that limited facilities, tools and media with high technology will not prevent learning process as long as teacher utilizes natural resources creativelly and innovatively to support achieving the purposes of learning. In learning social studies, environment is one of learning sources which can be utilized. According to Lestari (2016, p. 239), environment is one of the most important learning sources and has highly precious values in students' learning process.

Asy-Syuro Mosque is one of social studies learning source which utilizes surroundings environment. Mosque is a worship place broadly (ghairu mahdhah) as long as it is used in sharia/Islamic boundaries, such as development center to protect, empower and unite people, and other forms of worship. As proposed by Jannah (2016, p. 1823 ), at least there are seven roles of mosque as supporting life of society, those are: ritual (hablumminallah), social, society, economy, education, da'wah, politics, and health. Besides its role for ritual, Asy-Syuro mosque has other roles as fighting place, fortress, shelter and so on.

Learning resources are all things that can be used in the learning process (Winataputra, 2007, p. 20). The components of learning resources, according to AECT (in Komalasari 2010, p. 108), include: Messages, People, Materials, Tools, Techniques, and Background / Environment. In this case, the Asy-Syuro Mosque is included into the type of "Message" and "Environment" components. While learning resources, according to (AECT) in Setiani (2010, p. 120), when viewed from their origins, can be grouped into two parts, namely: Learning resources by design and Learning resources by utilization. In this case, the Asy- syuro Mosque is included in the category of Learning resources by utilization.

\section{METHOD}

The approach used in this study is a qualitative approach since the issue of "The Dynamics of Asy-Syuro Mosque's Role in Cipari Village in 1912-2015 as Social Studies Learnings Source" contains values, customs, norms, ideas, and symbols that are applied in society, so it requires serious and careful observation in finding the depth of a problem. Creswell (2008, p. 46) said in his book "Educational Research", qualitative research is a type of research in which researchers are highly dependent on information from objects or participants on a broad scope, general questions, and the data collection consisting mostly of words or texts from participants. Besides, it requires explaination and analysis of words and conducting research subjectively.

The method used in this research is the case study method. Creswell (2010, p. 20) explains that a case study is a research strategy in which researchers carefully investigate a program, event, activity, process, or group of individuals. Cases are limited by time and activity, and researchers gather complete information using various data collection procedures based on a predetermined time. Another qualitative research feature is it makes people as instruments for collecting data. The participants in this study were the Family of the Mosque's Founder, the Board of the Mosque's Management, Community Elders of Cipari Village, Teachers of Social Science and five students of MTs Ponpes Cipari. The location of this study is Asy-Syuro Mosque which is located in the Cipari Village area, Sukarasa Village, Pangatikan District, Garut Regency, West Java Province. In this study, the researcher only used three Participatory data collection techniques, namely: Observation, Indepth interviews, and Documentation studies. In qualitative research, the research instrument is the researcher herself. As explained by Sugiyono (2005, p. 59), in qualitative research, 
the instrument or research tool is the researcher him/herself.

After collecting the data, the next step was doing the analysis. The researcher used three stages, namely: Data Reduction, Data Presentation, and Drawing Conclusions. Miles and Huberman (in Gunawan, 2013: pp. 210212) states "three stages that must be done in analyzing research data are Data Reduction, Data Display, and Conclusion Drawing / Verification. Research can be said to be valid, if the data used are in accordance with what was reported and what happened in the field. Therefore, the researcher conducted a 3-staged creativity test as proposed by Sugiyono (2002, p. 270). He states that Data Creation Test in qualitative research could be carried out with extended observations, increased persistence in research, triangulation, discussion with peers, negative case analysis and member check.

\section{RESULTS AND DISCUSSION}

The results of this study can be seen in the discussion below.

\section{a. The role of the Asy-syuro Mosque in 1912-1945 as a source of learning.}

Asy-syuro Mosque in Pre-Independence Period (1912-1945) was used as a place of fighting, both defending Religion and defending the State of Indonesia. According to some informants and some literatures, Cipari Mosque or now it's known as Asy-syuro Mosque was built in 1895 and completed in 1934. The mosque is believed to be the oldest mosque in Garut, because it was once used as the basis of struggle by several prominent figures. This is proven by the initial purpose of establishing this mosque, which is not only for a worship place, but there are three (3) main roles, those are: First, the center of charismatic leader (a gathering place for the Islamic clerics and political figures of Syarikat Islam, such as Cokro Aminoto, K. H Agus Salim, Aem Sangaji, and others). Second, the center of power where Cipari people were very militant in fighting colonialism during the colonial period. Third, as a center of activity, namely as a center for religious activities, a center for social activities, and a center for political activities. The reason why this mosque used as a center of political activity was because Cipari was the strongest Sarekat Islam branch in Indonesia at that time.

It can be seen, that the establishment of the Asy-syuro mosque did have an influence or role in building political awareness of the Cipari village community in the 1800s. Many religious leaders and Muslim communities in Garut became members of SI (September 10, 1912), which made Garut become the second largest number of members after Manado. Then, the Cipari branch of SI was formed in 1914 under the leadership of K.H Andrai, Ny. $\mathrm{Hj}$ Mutiah, and K. H Hermaen. This organization was used to channel political aspirations towards the existence of the Dutch Colonial as a colonizer of the Republic of Indonesia. In 1927, the SI Congress was held in Cipari and resulted in a change of name to be Partai Sarekat Islam (PSI). However, in 1929, it was refined to become Partai Sarekat Islam Indonesia (PSII) with the aim of achieving national independence on the basis of the Islamic religion. This shows that the political awareness of the people of Garut, especially in Cipari, increased rapidly so it made the Dutch Colonial Government feel uneasy and finally commit terror many times with the aim of the people wanting to withdraw from political affairs. It can be seen from the many small holes caused by bullets that penetrated the walls of the mosque.

During the fighting against the Dutch invaders, the thick walled building became a fortress as well as a place for shelter for Cipari residents. The four-story mosque tower is quite strategic to lurk and make a machine gun storage area to block enemy attacks. The Asysyuro Mosque was even used as a storage area for firearms because the Cipari pesantren at that time had a santri army battalion. This mosque is often used as a place for war training, even as the public kitchens of freedom fighters and a shelter for refugees of Siliwangi army fighters and their families from Yogyakarta. Asy-syuro Mosque created local security defenses such as Darussalam's civil defense which was armed by the Kodim. The students were also trained in martial art for self defense. The famous Mohammad Roem and HOS Cokroaminoto are said to often visit Asysyuro mosque.

At that time, Asy-syuro Mosque often invited Sarekat Islam leaders to visit, worship together, study religious knowledge together, gather, and hold talks while discussing the fighting for Indonesian independence. Therefore, the name of the mosque is "Asysyuro" which means deliberation. 
The role of the Asy-syuro mosque in 1912-1945 was closely related to the Organization of the United Islamic Trade Movement and the Indonesian War of Independence against the Netherlands. Therefore, Asy-syuro Mosque is suitable to be used as a source of social studies learning because one of the materials in the eight grade class is Chapter IV which discusses the Arrival of Western Nations to Indonesia (the Netherlands) and the National Movement Organization (Sarekat Dagang Islam). This source can develop knowledge, raise students' fighting spirit and love for the Indonesian homeland and build skills such as critical thinking and communication skills.

\section{b. The role of the Asy-syuro Mosque in 1949-2015 as a Social Studies Learning Source}

As expressed by several informants and also written in some literature, the Asy-syuro Mosque in the Post-Independence period (1949-2015) was not only used as a place to receive guests, but it was still used as a place of fighting. In addition to the fighting against the Netherlands invaders, Asy-syuro Mosque was also used for the fighting against the nation itself, which is the DI / TII. In 1949-1958 there were several attacks from DI / TII to Cipari Village up to around 52 attacks. In DI / TII attack on May 7, 1949, there were no fatalities, but there was torture against some people in Pesantren Darusallam Cipari. This attack occurred at night at $10 \mathrm{pm}$ when the full moon appeared. According to a number of informants, in the 1950s, DI / TII violence was increasing, people in Cipari did not sleep and took refuge in the darkness of the night. On April 17, 1952, DI / TII forces attacked the K. $\mathrm{H}$ Yusuf Taudzirie's pesantren again after evening prayer (Isha prayer). Cipari residents fled to Asy-syuro Mosque. DI / TII attacks began to recede after midnight (near dawn). On August 5, 1952, DI / TII forces rallied Cipari Village again.

During the Darul Islam / Tentara Islam Indonesia (DI / TII) rebellion, Asy-syuro mosque was used as a shelter for refugees and care place for wounded troops. Also, during the G30S / PKI period, Asy-syuro mosque was used as a place of fight against PKI, defense, protection and public kitchen. As a result of DI / TII attack, the activities of the pesantren were halted because the boarding houses were burnt down. Then, over time and the attacks of DI / TII had stopped, the Cipari's pesantren program was increasingly encouraged. In 2015, the progress of the Cipari's pesantren program was evident. It was intially only used as a place to read the Qur'an, now the mosque is used as a place to support other Cipari pesantren education programs, such as: Sima'an Alqur'an, Marhalah, Muhadoroh, deposits and muraja'ah of the Qur'an, as well as khataman and graduation of students who have memorized 30 Juz of the Quran.

From the explanation above, teachers can develop students' knowledge by linking it to ninth grade class' materials related to DI / TII and G30S / PKI, and can develop students' character and skills, including: Social kindness, Commitment, Honesty, Orderly, Responsible, Trustful, and Trustworthy Cooperation in struggle. Besides, teacher cab develop the skills to memorize the Qur'an, communicate, collaborate, and think critically in solving problems.

c. The Changing Role of the Asy-syuro Mosque in 1912-1945 in seven aspects (Worship, Social, Economic, Education, Da'wah, Politics, and Health).

In 1912-1945, Asy-syuro Mosque underwent a significant change in role. These changes can be seen from the following seven aspects: 1) Worship, has increased. It can be shown from the increasing the size of the mosque and more worship activities are carried out in the mosque, such as: five-time prayers, Eid prayer, Eclipse prayer, Teraweh prayer, Thursday night recitation, and Slaughtering of sacrificial animals (in Eid Adha). In this case, teachers can take values from these ritual activities such as social, leadership, and economic values. Then, students can also emulate these activities by practicing in schools such as Dhuha / zuhur prayers together. 2) Social, has increased. It can be seen from the increasing social activities in the mosque, such as: gathering among groups, Lebaran culture, cleaning up the mosque together, and aqiqah activities. In this case, the teacher can associate with seventh grade class materials, which are 
Social Interaction related to Cooperation, and Flora and Fauna, and raise the students' care and love for environmental and Social kindness. 3) Economy, Unchanged. This means that it is still only used as a donations collectors / infak, zakat and endowments/wakaf. This can be linked to seventh grade class material on the Motive of Economic Action and increasing social life and economic life of students. 4) Education, has increased. It can be seen from the increasing pesantren programs that involve mosques, such as: Rote of memorization, Muroja'ah, Marhalah, Muhadoroh, Haol, Sima'an, and the Qur'anic verses. This can raise commitment and responsibility for students with orderly and honest attitude, and emulate the founding figures of the Asy-syuro Mosque. 5) Da'wah, Increased. At first, there were only da'wah on Tuesday initiated by K.H Abdul Kudus. But now, there are Saturday and Saturday evenings initiated by K.H Bunyamin. In this case, the teacher can instill students' social, religious and economic value. 6) Politics, has decreased. Initially, the mosque was used as a place of fighting, shelter, and a place of refuge; now, it is only used for deliberation and receiving guests. In this case, teachers can raise a fighting spirit, patriotism, and student cooperation by linking it to eight grade class material and ninth grade class material of the background on the arrival of western nations (the Netherlands), the Organisasi Pergerakan Nasional (SDI), DI / TII, G30S / PKI, and the war for Indonesian Independence. 7) Health, has decreased. It was once used as a place of treatment for victims of injuries due to attacks; now, it has no role in the health sector. In this case, teachers can increase students' social life to help each other.

\section{CONCLUSION}

First, Asy-syuro Mosque of Cipari Village in 1912-1945 had important roles in the fighting against the Netherlands invaders. This mosque was used as a base of fighting, a stronghold, a place of protection, a place for deliberation by SI members to plan the strategy of the fighting at that time, the place of the SI Congress, and a place for firearms. Asy-syuro Mosque is closely related to the Organisasi Pergerakan Sarekat Dagang Islam and the Indonesian War of Independence against the Netherlands. Thus, it is suitable as a source of social studies learning. Besides being able to develop students' knowledge by linking the Asy-syuro mosque to KD 3.4 material for eight grade class, which is related to the background of the arrival of western nations and national organizations, teachers can also build students' character and raise critical thinking skills and communication skills through values contained in the event.

Second, the Asy-Syuro Mosque in the Post-Independence period (1949-2015) was not only used as a place of worship, but it was also used as a place of fighting. In addition to the struggle against the Netherlands invaders, the Asy-syuro Mosque was also used for the struggle against the nation itself, namely the DI / TII. During 1949-1958, DI / TII attacked Cipari Village dozens of times. This made AsySyuro Mosque a place of refuge and a place of shelter from DI / TII attacks. As a result of the attack, DI / TII Pesantren activities were stopped because of the destruction of the santri lodges. Therefore, Asy-syuro mosque was used as a support for Cipari's pesantren education activities until 2015. The progress of the pesantren was evident and increasingly encouraged. Asy-syuro Mosque is increasingly used as a place to carry out major pesantren programs such as, Marhalah, Muhadoroh, Sima'an Al-Qur'an, Haol of the mosque's founder, and big graduation activities / students' Khataman of 30 jus of the Quran. In addition, teachers can develop students' knowledge by linking the Asy-syuro mosque to ninth grade class' K.D 3.4 material, which is related to the DI / TII Movement, and the G30S / PKI. Moreover, it can also raise a spirit of learning, commitment, cooperation, and responsibility of students through the values contained in the event.

Third, the role of the Asy-syuro Mosque in 1912-2015 underwent changes in seven aspects (Worship, Social, Economic, Education, Da'wah, Politics, and Health). (1) Worship. Increasing in quantity, that is by increasing the size of the mosque, (2) Social. Increasing the quantity of community activities in the mosque, (3) Economy. Didn't make any change. (4) Education. Increase in quality and quantity. The number of mosque users and visitors increased and the number of activities increased. (5) Da'wah. Increase. Da'wah activities carried out in the mosque. (6) Politics. Decrease. The reason is because the conditions of different times. (7) Health. 
Decrease. It is similar to the case of Politics: due to differences in conditions. These seven aspects can be used as a source of learning. Besides, it can be applied to develop social science knowledge. Teachers can also increase fighting spirit, patriotism, social life, religious attitude, and so on. Then, students' skills in working together, communicating, and critical thinking can be developed by teachers in the learning process as the objectives of Social Studies Learning which are stated in the Education Curriculum of 2013. In this case, Asy-syuro mosque is a component of learning resources of the type of "Message" and "Environment" as well as the types of learning resources that are available and can be utilized (Learning Resources by Utilization).

\section{ACKNOWLEDGMENT}

To the Social Studies Education Study Program, Faculty of Social Sciences Education, Universitas Pendidikan Indonesia for the publication of this article in the Journal of Social Studies Education Study Program.

\section{REFERENCES}

Banks, A. J. (1990). Teaching Strategies for the Social Studies Inkuiry, Valuing, and Decision Making. New York: Longman.

Sapriya. (2009). Pendidikan IPS Konsep dan Pembelajaran. Bandung: Remaja Rosdakarya.

Hasanah, L., \& Darmawan, W. (2016). Pemanfaatan Buku Teks IPS untuk mengembangkan Keterampilan Menyimak siswa Siswa (Penelitian Tindakan Kelas di Kelas VII-F SMPN 13 Bandung). International Journal Pedagogy of Social Studies, 1(2), 2.

Wijaya, A. (2016). Pemanfaatan Ecocomunity dan Social Networking sebagai sumber dan media pembelajaran IPS dalam membangun Kecerdasan Ekologis peserta didik. International Journal Pedagogy of Social Studies, 1(2), 5.

Holilah, M. (2015). Kearifan Ekologis Budaya Lokal Masyarakat Adat Cigugur Sebagai Sumber Belajar Ips. Jpis, Jurnal Pendidikan Ilmu Sosial, 24(2), 165.

Valentine, D., A. (2015). Peningkatan Ecoliteracy siswa dalam pemanfaatan Kebun Karet sebagai sumber pembelajaran IPS. JPIS, Jurnal Pendidikan Ilmu Sosial, 24(2), 224.

Lestari, E. (2016). Mengembangkan Kemampuan Berpikir Kritis peserta didik dengan Metode Inkuiri melalui Sumber Kerajinan Sarung Goyor Ramah Lingkungan (Penelitian Tindakan Kelas di SMPN 1 Tawangsari Kab. Sukoharjo). International Journal Pedagogy of Social Studies, 1(2), 232.

Jannah, N. (2016). Revitalisasi Peranan Masjid di Era Modern. Analytica Islamica, 5(1), 128-129.

Winataputra, dkk. (2007). Civic Education: Konteks, Landasan, Bahan Ajar, dan Kultur Kelas. Bandung: Program Studi Pendidikan Kewarganegaraan SPs UPI.

Komalasari, K. (2010). Pembelajaran Kontekstual: Konsep dan Aplikasi. Bandung: Refika Aditama.

Setiani, R. (2010). Pemanfaatan sumber Internet sebagai Sumber Belajar. Jurnal Pendidikan Ekonomi Dinamika Pendidikan, 5( 2), 120.

Sjamsuddin, H. (2012). Metodologi Sejarah. Yogyakarta: Penerbit Ombak.

Susanto, A. (2014). Pengembangan Pembelajaran IPS di Sekolah Dasar. Jakarta: Kencana Prenada. 